\title{
Characteristics of the complex modulus of recycled cold mix with foamed bitumen and recycled concrete aggregate
}

\author{
Przemysław Buczyński ${ }^{1, *}$, Marek Iwański ${ }^{1}$, \\ ${ }^{1}$ Kielce University of Technology, Department of Transportation Engineering, Faculty of Civil Engineering and Architecture, \\ al. Tysiąclecia Państwa Polskiego 7, 25-314 Kielce, Poland
}

\begin{abstract}
This article presents research on recycled cold mix with foamed bitumen (MCAS) containing recycled concrete aggregate. The primary concept driving this research was to determine if recycled concrete aggregate (RC) could be used as a substitute for reclaimed asphalt pavement (RAP). Recycled concrete aggregate was used in the MCAS mix in amounts ranging from $20 \%, 60 \%$ and $80 \%$. The reference mix was the MCAS mix containing 50\% reclaimed asphalt pavement (RAP) and virgin aggregate. Identical 0/31.5-mm continuously graded dolomite virgin aggregate was used in all mixes. $2.5 \%$ foamed bitumen (FB) and 2.0\% CEM I 42.5R Portland cement (PC) were used to increase the cohesion of the mineral mix. Foamed bitumen was produced from 50/70 penetration paving bitumen. The behaviour of the recycled base course was tested in the range of cyclic sinusoidal strain with amplitude $\varepsilon 0=25-50 \mu \varepsilon$. The tests were carried out in the $\left(-7^{\circ} \mathrm{C}, 5^{\circ} \mathrm{C}, 13^{\circ} \mathrm{C}, 25^{\circ} \mathrm{C}, 40^{\circ} \mathrm{C}\right)$ temperature and $(0.1 \mathrm{~Hz}, 0.3 \mathrm{~Hz}, 1 \mathrm{~Hz}, 3 \mathrm{~Hz}, 10 \mathrm{~Hz}, 20$ $\mathrm{Hz}$ ) loading time range. The complex modulus was tested in a direct tension-compression test on cylindrical samples (DTC-CY) in accordance with EN 12697-26. The results of the tests were used to assess the complex modulus $\left(E^{*}\right)$, phase angle $(\varphi)$ and complex modulus components $\left(E_{1}\right)$ and $\left(E_{2}\right)$.Tests of the mixes indicate that recycled concrete aggregate can be used in recycled cold mixes in amounts of up to $80 \%$. Increasing the amount of recycled concrete aggregate does not cause excessive stiffness of the recycled mix in comparison with the reference mix. The tests did not demonstrate a significant difference in terms of the phase angle $(\varphi)$, which indicates a similar content of the viscous part and elastic part in the obtained complex modulus for the reference mix (RAP + MCAS) and the mix containing recycled concrete aggregate $(\mathrm{RC}+\mathrm{MCAS})$.
\end{abstract}

\section{Introduction}

The expansion of road infrastructure and availability of a wide range of construction methods [1-5] give more opportunities when designing flexible $[6,7]$, semi-rigid $[6,7]$ and rigid pavements [8]. The management of waste materials from road pavements was discussed in papers by many authors [1, 3, 4]. However, the following conditions (among others) have to be met in order to use waste materials as full-value materials: the physical and mechanical parameters of the evaluated waste material have to be no worse than the parameters of new aggregate, or the mix where such material is to be used has to achieve the required parameters. The primary reason behind the search for ways of managing waste materials is to reduce the consumption of the "new material" and reduce environmental deterioration.

The use of reclaimed asphalt pavement (RAP) in hot mix asphalt (HMA) was assessed in the studies of Kowalski et. al [9], Bańkowski et al. [10] and Izaks et. al [11]. The use of waste materials in the form of recycled aggregate, reclaimed asphalt pavement and mineral dust in recycled cold mix with foamed bitumen was discussed in papers presented by authors $[12,13]$. Similar research on evaluating the use of waste materials in recycled cold mixes using bitumen emulsion as the binder was discussed in [14]. Using reclaimed asphalt pavement in hot mix asphalt has both financial and environmental benefits. Adding RAP to hot mix asphalt reduces the amount of new bitumen, aggregate, sand and filler. The benefits are smaller when recycled concrete aggregate (RCA) is used because this material type can only be used as aggregate.

The waste material such as RCA, due to its structure, i.e. high water absorption and porosity, has limited application. In the available studies, using reclaimed asphalt pavement is limited to adding recycled concrete aggregate (RCA) to cement concrete as a substitute for new aggregate. Research in this regard was carried out by many researchers [15-18]. The structure of RCA limits its possible applications in hot mix asphalt. This is due to its high porosity and bitumen absorption by the aggregate and also due to the relatively low resistance to fragmentation. More bitumen would have to be added to HMA containing RCA in order to provide the required bitumen content. This approach is uneconomic and is not used in practice.

* Corresponding author: p.buczynski@tu.kielce.pl 
There are studies where recycled concrete aggregate was used in road base courses. In [19], the authors presented research on the use of RCA in road base made of hydraulically unbound mix. However, RCA was mixed with natural limestone aggregate. The application of recycled concrete aggregate (RCA) in recycled cold mixes with $20 \%$ foamed bitumen (MCAS - foamed bitumen recycled cold mix) has been presented by the authors of [20]. The quality of MCAS using RCA was tested with respect to its main physical and mechanical parameters, i.e. ITS, TSR, ITSM.

The key issue when using a large quantity of recycled concrete aggregate (RCA) in recycled cold mixes with foamed bitumen is the stiffness modulus of the mix. The Portland cement present in recycled concrete aggregate in the form of chips mixed with aggregate may increase stiffness due to secondary hydration. Additionally, the interaction of Portland cement in MCAS with the cement in RCA may intensify the increase of the stiffness of the mix. That is why it seems necessary to determine the rheological properties (complex modulus $\mathrm{E}^{*}$ and phase angle $\varphi$ ), which can be used to accurately assess the behaviour of recycled cold mixes containing foamed bitumen in the situation where it contains recycled concrete aggregate.

This article presents studies of recycled cold mix with foamed bitumen containing recycled concrete aggregate as a substitute for the conventionally used reclaimed asphalt pavement. The primary concept driving these studies was to determine if recycled concrete aggregate (RCA) could be used as a substitute for reclaimed asphalt pavement (RAP). Recycled concrete aggregate was used in the MCAS mix in amounts of $20 \%, 60 \%$ and $80 \%$. The studies involved tests of MCAS regarding the assessment of the stiffening impact of recycled concrete aggregate (RCA). The reference mix was the MCAS mix containing 50\% RAP and virgin aggregate (VA). 0/31.5-mm continuously graded dolomite virgin aggregate was used in all mixes. In the reference mix, the amount of virgin aggregate was $50 \%$, and in the mixes with recycled concrete aggregate (MCAS) the amount was the remainder of $100 \%$, depending on the amount of added RCA. Complex modulus $E^{*}$ was tested in the range of cyclic sinusoidal strain with amplitude $\varepsilon_{0}$ from 25 to 50 $\mu \varepsilon$ [21-23]. The tests were carried out in the $\left(-7^{\circ} \mathrm{C}, 5^{\circ} \mathrm{C}\right.$, $\left.13^{\circ} \mathrm{C}, 25^{\circ} \mathrm{C}, 40^{\circ} \mathrm{C}\right)$ temperature and $(0.1 \mathrm{~Hz}, 0.3 \mathrm{~Hz}, 1$ $\mathrm{Hz}, 3 \mathrm{~Hz}, 10 \mathrm{~Hz}, 20 \mathrm{~Hz}$ ) loading time range. The complex modulus was tested in a direct tensioncompression test on cylindrical samples (DTC-CY) in accordance with EN 12697-26 [23].

The first step of this testing plan was to design the recycled cold mix with foamed bitumen in terms of its RCA content.

\section{MCAS mix design and testing methods}

The laboratory design of the recycled cold mix with foamed bitumen was prepared in accordance with [24, 25], and it contained the following ingredients: reclaimed asphalt pavement (RAP), recycled concrete aggregate (RCA), 0/31.5 continuously graded crushedstone dolomite virgin aggregate (VA), CEM I $42.5 \mathrm{R}$ Portland cement and foamed bitumen.

Foamed bitumen was produced from 50/70 penetration paving bitumen. The quality of foamed bitumen was assessed based on the maximum Expansion Ratio $\left(\mathrm{ER}_{\mathrm{m}}\right)$ and half-life $\mathrm{H}-1$ [24]. The parameters conformed to the guidelines [25].

Recycled concrete aggregate was obtained by milling it off $\mathrm{C} 16 / 20$ cement concrete layers. The physical and mechanical parameters are presented in table 1 .

Table 1. Properties of recycled concrete aggregate (RCA)

\begin{tabular}{|c|c|c|c|c|}
\hline Property & Test & u.m. & Result & Symbol \\
\hline $\begin{array}{l}\text { Dimension } \\
\text { d/D }\end{array}$ & EN 933-1 & - & - & $0 / 63$ \\
\hline $\begin{array}{l}\text { Particle size } \\
\text { distribution }\end{array}$ & EN 933-1 & - & - & $\mathrm{G}_{\mathrm{A}} 85$ \\
\hline Density & $\begin{array}{c}\text { EN } 1097- \\
6\end{array}$ & $\mathrm{Mg} / \mathrm{m}^{3}$ & 2.28 & 2.28 \\
\hline Shape index & EN 933-4 & $\%$ & 6.0 & $\mathrm{SI}_{20}$ \\
\hline $\begin{array}{l}\text { Percentage of } \\
\text { crushed and } \\
\text { broken } \\
\text { surfaces }\end{array}$ & EN 933-5 & $\%$ & $99 / 0$ & $\mathrm{C}_{90 / 3}$ \\
\hline $\begin{array}{c}\text { Frost } \\
\text { resistance }\end{array}$ & $\begin{array}{c}\text { EN 1367- } \\
1\end{array}$ & $\%$ & 3.4 & $\mathrm{~F}_{4}$ \\
\hline $\begin{array}{l}\text { Resistance to } \\
\text { fragmentation }\end{array}$ & $\begin{array}{c}\text { EN 1097- } \\
2\end{array}$ & $\%$ & 38.5 & $\mathrm{LA}_{40}$ \\
\hline Absorptivity & $\begin{array}{c}\text { EN } 1097- \\
6\end{array}$ & $\%$ & 4.9 & $\mathrm{WA}_{24} 4.9$ \\
\hline $\begin{array}{c}\text { Frost } \\
\text { resistance }\end{array}$ & $\begin{array}{c}\text { EN 1367- } \\
1\end{array}$ & $\%$ & 3.65 & $\mathrm{~F}_{4}$ \\
\hline
\end{tabular}

The virgin aggregate used in the recycled cold mix with foamed bitumen is natural crushed-stone dolomite aggregate. Aggregate properties are presented in table 2.

Table 2. Properties of dolomite aggregates 0/31.5 (VA)

\begin{tabular}{|c|c|c|c|c|}
\hline Property & Test & u.m. & Result & Symbol \\
\hline $\begin{array}{l}\text { Dimension } \\
\text { d/D }\end{array}$ & EN 933-1 & - & - & $0 / 31$ \\
\hline $\begin{array}{l}\text { Particle size } \\
\text { distribution }\end{array}$ & EN 933-1 & - & - & $\mathrm{G}_{\mathrm{A}} 85$ \\
\hline Density & $\begin{array}{c}\text { EN 1097- } \\
6\end{array}$ & $\mathrm{Mg} / \mathrm{m}^{3}$ & 2.80 & 2.80 \\
\hline Shape index & EN 933-4 & $\%$ & 16.0 & $\mathrm{SI}_{20}$ \\
\hline $\begin{array}{c}\text { Flakiness } \\
\text { index }\end{array}$ & EN 933-3 & $\%$ & 14.0 & $\mathrm{FI}_{20}$ \\
\hline $\begin{array}{l}\text { Percentage of } \\
\text { crushed and } \\
\text { broken } \\
\text { surfaces }\end{array}$ & EN 933-5 & $\%$ & $98 / 2$ & $\mathrm{C}_{90 / 3}$ \\
\hline $\begin{array}{c}\text { Frost } \\
\text { resistance }\end{array}$ & $\begin{array}{c}\text { EN } 1367- \\
1\end{array}$ & $\%$ & 3.4 & $\mathrm{~F}_{4}$ \\
\hline $\begin{array}{l}\text { Resistance to } \\
\text { fragmentation }\end{array}$ & $\begin{array}{c}\text { EN 1097- } \\
2\end{array}$ & $\%$ & 23 & $\mathrm{LA}_{30}$ \\
\hline $\begin{array}{l}\text { Abrasion } \\
\text { resistance }\end{array}$ & $\begin{array}{c}\text { EN } 1097- \\
1\end{array}$ & $\%$ & 17.5 & $M_{\mathrm{DE}} 20$ \\
\hline
\end{tabular}


The possibility of using recycled concrete aggregate was assessed for three mixes with different RCA content and for the reference mix. The reference mix contained the typical amount of reclaimed asphalt pavement, i.e. $50 \%$ RAP and 50\% virgin aggregate (VA). In order to compare the test results, the remaining ingredients, i.e. cement and amount of bitumen in the reference $\mathrm{m} \backslash \mathrm{ix}$ were the same as in the mix with recycled concrete aggregate. The design particle size distribution curves are depicted in figure 1.

In order to achieve the required particle size in the Marshall test [6], mineral materials were passed through a 22.4-mm sieve. The amount of binders and the main parameters of recycled cold mixes with foamed bitumen are presented in table 3 .

Table 3. Main parameters of analysed mixes

\begin{tabular}{|c|c|c|c|c|c|c|}
\hline Property & Symbol & u.m. & $\begin{array}{l}\text { MCAS } \\
20 \% \text { RC } \\
80 \% \text { VA } \\
\end{array}$ & $\begin{array}{l}\text { MCAS } \\
60 \% \text { RC } \\
40 \% \text { VA } \\
\end{array}$ & $\begin{array}{l}\text { MCAS } \\
80 \% \text { RC } \\
20 \% \text { VA } \\
\end{array}$ & $\begin{array}{c}\text { MCAS } \\
50 \% \text { RAP } \\
50 \% \mathrm{VA} \\
\end{array}$ \\
\hline Bitumen/cement content & $\mathrm{B} / \mathrm{C}$ & {$[\%]$} & $\begin{array}{l}\mathrm{B}=2.5 \\
\mathrm{C}=2.0\end{array}$ & $\begin{array}{l}\mathrm{B}=2.5 \\
\mathrm{C}=2.0\end{array}$ & $\begin{array}{l}\mathrm{B}=2.5 \\
\mathrm{C}=2.0\end{array}$ & $\begin{array}{l}\mathrm{B}=2.5 \\
\mathrm{C}=2.0\end{array}$ \\
\hline $\begin{array}{l}\text { Water resistance, } \\
\text { according to Wiertgen } 2006 \text { [33] }\end{array}$ & TSR & & 71.8 & 86.1 & 92.6 & 83.0 \\
\hline Air void content, according to PN-EN $12697-8$ & $\mathrm{~V}_{\mathrm{m}}$ & {$[\%]$} & 15.3 & 11.4 & 10.4 & 13.8 \\
\hline $\begin{array}{l}\text { Indirect tensile strength, according to PN- } \\
\text { EN } 12697-23\left(\mathrm{~T}=25^{\circ} \mathrm{C}\right)\end{array}$ & ITS & {$[\mathrm{kPa}]$} & 296 & 428 & 389 & 528 \\
\hline
\end{tabular}

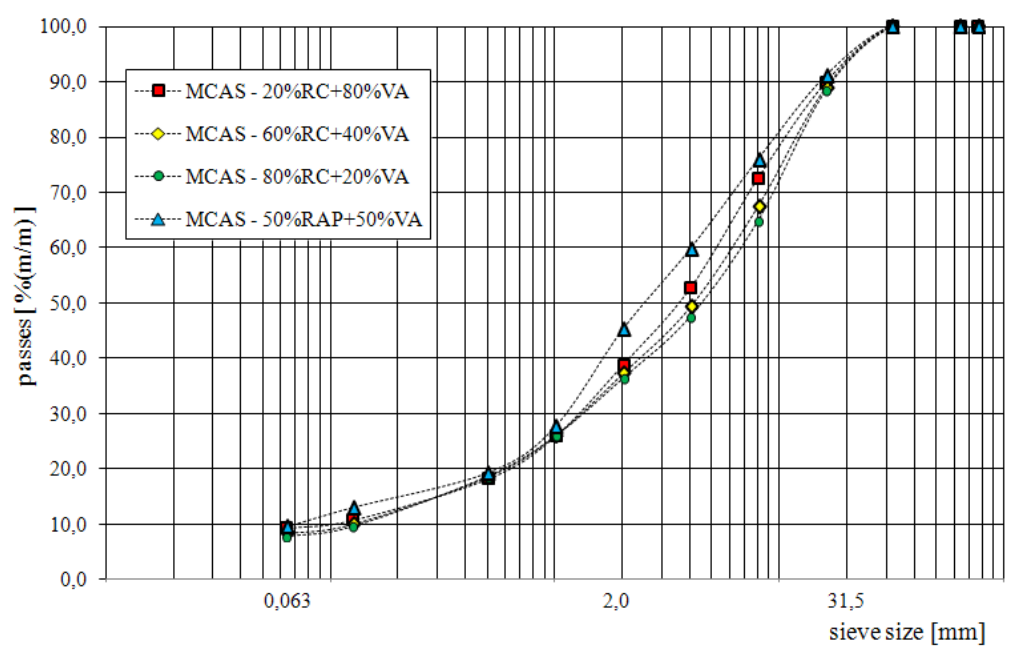

Fig. 1. Particle size distribution of analysed MCAS mixes

The visco-elastic properties of recycled cold mix with foamed bitumen (MCAS) were assessed by testing the complex modulus in accordance with standard [23].

The recycled cold mix with foamed bitumen was prepared under laboratory conditions. After a homogeneous mix had been obtained, the samples were compacted in a gyratory compactor in accordance with standard [26]. The settings of the gyratory compactor were determined based on references [26-28]. The number of turns was selected individually for the mixes in order to achieve the density at which the air void content of the recycled cold mix with foamed bitumen was $\mathrm{V}_{\mathrm{m}}=12.0 \%$. The diameter of MCAS samples prepared for the tests was, respectively, $\mathrm{D}=150 \mathrm{~mm}$, and height $\mathrm{H}=180 \mathrm{~mm}$. The samples were cured for 28 days at ambient temperature under conditions with humidity ranging from $40 \%$ to $70 \%$. The next stage involved cutting the samples out of the cylinders compacted in the gyratory compactor to diameter $\mathrm{D}=$ $100 \mathrm{~mm}$. This produced cylindrical samples for complex modulus testing with a size of $\mathrm{D}=100 \mathrm{~mm}$ and $\mathrm{H}=$ $180 \mathrm{~mm}$.

Complex modulus tests were carried out using the direct tension-compression testing method (DTC-CY), where the sample was subject to cyclic sinusoidal loading with small strain ranging [21-23]. In this experiment the level of strains was $25 \mu \varepsilon$. If the test had been performed outside of this strain range, this could have created irreversible strain in the tested sample, leading to incorrect determination of the complex modulus. The tests were carried out for five temperature levels $\left(-7^{\circ} \mathrm{C}, 5^{\circ} \mathrm{C}, 13^{\circ} \mathrm{C}, 25^{\circ} \mathrm{C}, 40^{\circ} \mathrm{C}\right)$ and six loading times $(0.1 \mathrm{~Hz}, 0.3 \mathrm{~Hz}, 1 \mathrm{~Hz}, 3 \mathrm{~Hz}, 10 \mathrm{~Hz}, 20 \mathrm{~Hz})$. The determined values of the complex modulus for recycled cold mixes with foamed bitumen were used to prepare master curve models. Master curve models were prepared using the Richards model [29], which was a modification of the model presented in report NCHRP 929: PP 02 [30]. This model can be classified as an asymmetric sigmoidal mathematical model. The asymmetry is modelled through the curve fitting 
parameter $(\lambda)$. The form of the asymmetric sigmoidal function is described by the following equation (1). The presentation of the master curve of the complex modulus uses the principle of time-temperature superposition. This requires adding the temperature shift factor $\left(\alpha_{T}\right)$ [31], which has been implemented in equation (1):

$$
\log \left|E^{*}\right|=\delta+\frac{\alpha}{\left[1+\lambda e^{\beta+\gamma \log \left(a+\dot{b} \cdot T+c \cdot T^{2}\right)}\right]^{1 / \lambda}}
$$

where: $\mathrm{E}^{*}$ - complex modulus, $\omega$ - angular frequency, $\delta$ - lower asymptote (master curve fitting parameter), $\alpha$ difference between upper and lower asymptote (master curve fitting parameter), $\lambda, \beta, \gamma$ - master curve fitting parameters, $\mathrm{T}$ - test temperature, $a, b, c$ - model parameters

\section{Master curves of the complex modulus of the analysed mixes}

The master curves of the complex modulus of recycled cold mix with foamed bitumen were defined using the assumptions of the time-temperature superposition principle $[30,32]$. To this end, the sigmoidal function was optimised by minimising the sum of squares of deviations for the determined complex moduli. As a result of adoption of specific model master curve, it was necessary to determine its parameters $(\alpha, \delta, \beta, \gamma, \lambda, a, b)$. The evaluation of the parameters is presented in table 4 .

Table 4. Fitting parameters for the master curve model

\begin{tabular}{cccccccc}
\hline \multirow{2}{*}{ Mix } & \multicolumn{7}{c}{ Master curve fitting parameters } \\
\cline { 2 - 8 } & $\alpha$ & $\delta$ & $\beta$ & $\gamma$ & $\lambda$ & $\mathrm{a}$ & $\mathrm{b}$ \\
\hline MCAS - 20\%RC+80\%VA & 2.033 & 2.033 & 0.437 & -0.191 & 0.100 & 2.575 & -0.009 \\
MCAS - 60\%RC+40\%VA & 2.054 & 2.054 & 0.859 & -0.161 & 0.100 & 2.848 & -0.007 \\
MCAS - 80\%RC+20\%VA & 2.187 & 2.187 & -0.508 & -0.131 & 0.100 & 2.031 & -0.024 \\
MCAS - 50\%RAP+50\%VA & 2.074 & 2.074 & 2.236 & -0.241 & 0.100 & 2.942 & -0.007 \\
\hline
\end{tabular}

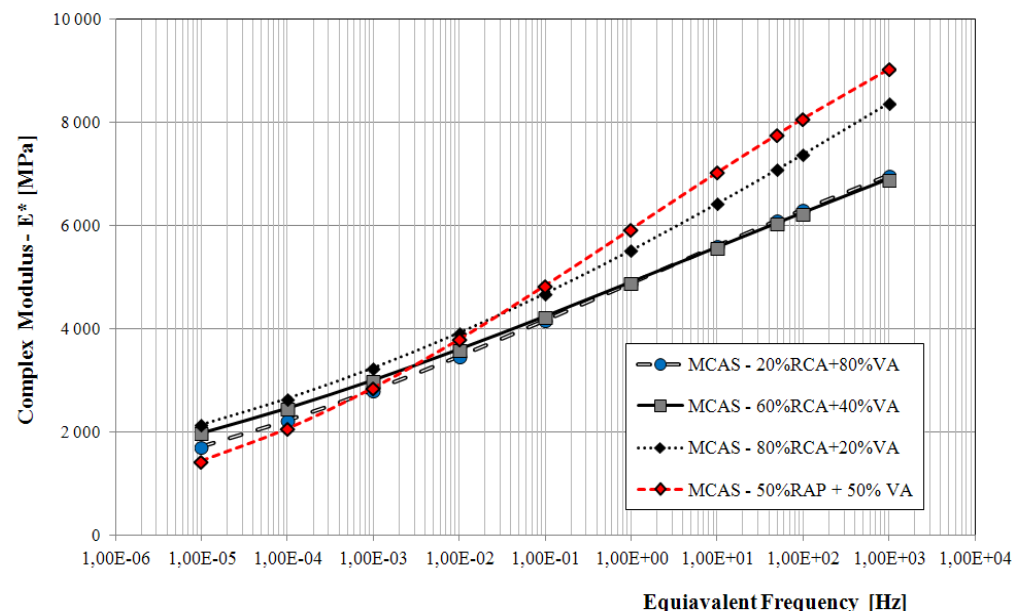

Fig. 2. Master curves for the analysed MCAS mixes $\left(\mathrm{T}_{\mathrm{ref}}=25^{\circ} \mathrm{C}\right)$

The goodness of fit of the complex modulus, for five temperature levels $\left(-7^{\circ} \mathrm{C}, 5^{\circ} \mathrm{C}, 13^{\circ} \mathrm{C}, 25^{\circ} \mathrm{C}, 40^{\circ} \mathrm{C}\right)$ and six loading times $(0.1 \mathrm{~Hz}, 0.3 \mathrm{~Hz}, 1 \mathrm{~Hz}, 3 \mathrm{~Hz}, 10$ $\mathrm{Hz}, 20 \mathrm{~Hz}),\left(\mathrm{E}^{*}\right)-$ tested modulus $\left(\mathrm{E}^{*}\right.$ exam. $)$ and modulus obtained through optimisation $\left(\mathrm{E}^{*}{ }_{\text {mod. }}\right)$ - was evaluated on the basis of their correlation. A graphical evaluation of the goodness of fit is presented in figure 3 . 


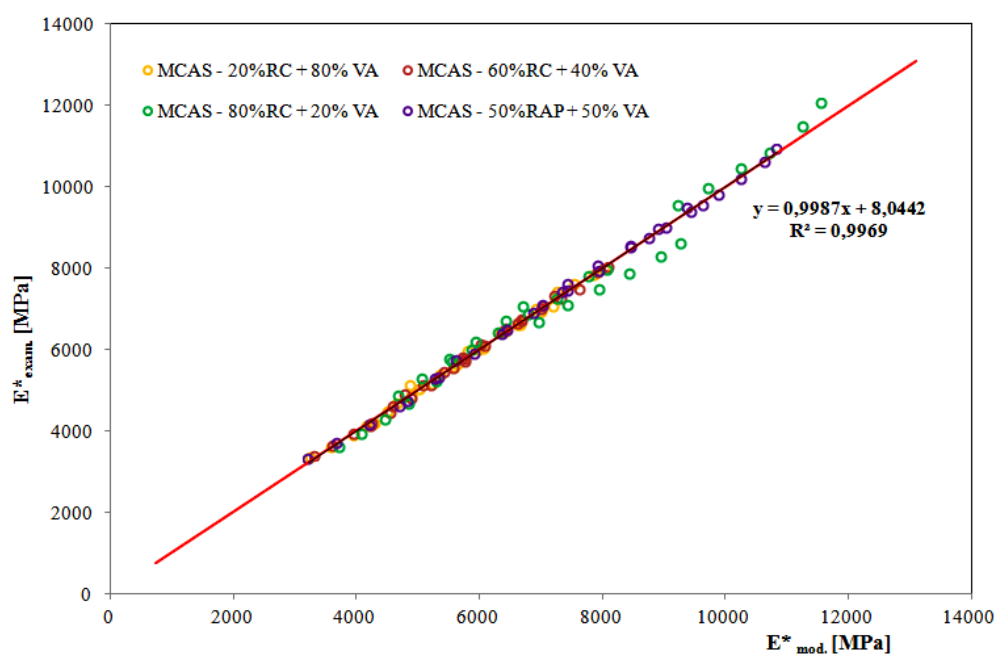

Fig. 3. Evaluation of the goodness of fit of complex modulus $E^{*}$ exam. to $E^{*}$ mod.

It should be noted that the fit of the tested complex moduli $\left(\mathrm{E}^{*}\right.$ exam. $)$ and the moduli obtained through optimisation $\left(\mathrm{E}^{*}{ }_{\text {mod. }}\right)$ is characterised by a very high coefficient of determination R2: 0.9969 (fig. 3). This is indicative of very high accuracy of the description of complex moduli using the time-temperature superposition principle.

The master curves clearly demonstrate (fig. 2) that the recycled concrete aggregate (RCA) used in the recycled mix does not increase the stiffness modulus in comparison with the reference mix (red line). The lowest values of the complex modulus were achieved by the MCAS recycled mix containing the lowest amount of recycled concrete aggregate (MCAS - 20\%RCA+80VA). It should be noted that increasing the amount of RCA to $60 \%$ resulted in an increase of the complex modulus for low frequencies/long loading time, whereas with low temperatures/short loading time the value of the complex modulus was the same as for the mix containing $20 \%$ RCA.

Increase of the value of complex modulus in the RCA content range of $20 \%$ to $80 \%$ depends on loading time/test temperature (time-temperature superposition principle). Increasing the RCA content of recycled cold mix with foamed bitumen caused the complex modulus to increase by approximately $30 \%$ for frequencies over $1 \mathrm{~Hz}$. Below this frequency $(<1 \mathrm{~Hz})$, however, the increase of the complex modulus was smaller, amounting to approximately $12 \%$. The change of the complex modulus for recycled cold mixes with foamed bitumen and recycled concrete aggregate is, in fact, linear. This is due to the absence of the ingredient responsible for the creep of the mix. Increase of the amount of bitumen in the recycled mix causes creep to appear at high temperatures. Such properties are typical to bituminous mixes [33-35].

The form of the master curve for the reference mix MCAS- $50 \% \mathrm{RAP}+50 \% \mathrm{VA}$ is similar to the form for bituminous mixes. The reclaimed asphalt pavement present in MCAS- 50\%RAP+50\%VA mixes combined with foamed bitumen contributes to an increase of the viscous part $\left(\mathrm{E}_{2}\right)$, reducing the complex modulus at low frequencies (long loading time). At low temperatures (for $50 \mathrm{~Hz}$ ), the reference mix has the highest complex modulus $\mathrm{E}^{*}=7550 \mathrm{MPa}$. However, increasing the loading time (for $0.001 \mathrm{~Hz}$ ) reduces the complex modulus to $2849 \mathrm{MPa}$. This represents a $64 \%$ decrease of the modulus. For the MCAS mix with recycled concrete aggregate, the decrease of the modulus, regardless of RCA content, is approximately $50 \%$.

Obtaining a lower decrease of the complex modulus is beneficial to the durability of the road pavement structure. In the summer season, it will not cause an excessive increase of horizontal and vertical strain on the bottom of the recycled MCAS base.

\section{Conclusion}

The tests and their analyses support the following conclusions:

- Using recycled concrete aggregate (RCA) in recycled cold mix with foamed bitumen does not increase complex modulus $\mathrm{E}^{*}$. Consequently, it can be found that using RCA does not contribute to the stiffness of the MCAS mix.

- Increasing the amount of recycled concrete aggregate in MCAS composition increased the value of complex modulus $E^{*}$. However, the maximum complex modulus values in the operating loading time range (from $0.01 \mathrm{~Hz}$ to $50 \mathrm{~Hz}$ ) are lower than the complex modulus achieved for the MCAS reference mix with reclaimed asphalt pavement.

- Recycled cold mix with foamed bitumen containing recycled concrete aggregate will be more resistant to creep than the reference mix with reclaimed asphalt pavement. This is due to the higher complex modulus obtained in the very short loading time corresponding to very low vehicle speed at an intersection.

Acknowledgment(s) The research results were developed as part of the project entitled " The innovative technology used the binding agent optymalization that provides the lond service life of the recycled base corse" within the scientific undertaking 
of Strategic Research and Development Program entitled "Modern Materials Technology" (TECHMATSTRATEG I), which is financed by the National Center for Research and Development (NCBiR).

\section{References}

1. D.C. Saha, J.N. Mandal, Laboratory Investigations on Reclaimed Asphalt Pavement (RAP) for using it as Base Course of Flexible Pavement, Procedia Engineering, 189, pp. 434-439, (2017).

2. B. Świeczko-Żurek, P. Jaskuła, J.A. Ejsmont, A. Kędzierska, P. Czajkowski, Rolling resistance and tyre/road noise on rubberised asphalt pavement in Poland, Road Materials and Pavement Design, 18(1), pp.151-167, (2017). doi.org/10.1080/14680629.2016.1159245

3. A. Chomicz-Kowalska, W. Gardziejczyk, M.M. Iwański, Moisture resistance and compactibility of asphalt concrete produced in half-warm mix asphalt technology with foamed bitumen. Constr. Build. Mater. 126 pp. 108-118. (2016). doi.org/10.1016/j.conbuildmat.2016.09.004

4. M.Dinis-Almeida, J.Castro-Gomes, C. Sangiorgi, S.E. Zoorob, M. Lopes Afonso, Performance of Warm Mix Recycled Asphalt containing up to $100 \%$ RAP. Constr. Build. Mater. 112, pp. 1-6, (2016). doi.org/10.1016/j.conbuildmat.2016.02.108

5. S. Li, F. Yang, Z. Liu, A new structure for continuously reinforced concrete pavement with road performance evaluation. Constr. Build. Mater. 157 pp. 1047-1052, (2017). doi.org/10.1016/j.conbuildmat.2017.09.087

6. J. Piłat, P. Radziszewski, Nawierzchnie asfaltowe. WKŁ, Warszawa, 2010. (in Polish)

7. J. Judycki, P. Jaskuła, M. Pszczoła, J. Alenowicz, B. Dołżycki, M. Jaczewski, D. Ryś, M. Stienss, Catalogue of typical flexible and semi-rigid pavements. Gdańsk University of Technology, Poland (in Polish) (General Directorate for National Roads and Motorways) (in Polish) (2014).

8. A. Szydło, P. Mackiewicz, R. Wardęga, B. Krawczyk. Catalogue of typical rigit pavements. Wrocław University of Technology, Poland (in Polish) (General Directorate for National Roads and Motorways) (in Polish) (2014).

9. K. Kowalski, J. Król, W. Bańkowski, P. Radziszewski, M. Sarnowski, 2017 Thermal and Fatigue Evaluation of Asphalt Mixtures Containing RAP Treated with a Bio-Agent. Applied Sciences, 7(3):216, pp 1-11, (2017). doi:10.3390/app7030216

10. W. Bańkowski, D. Sybilski, J. Król, K. Kowalski, P. Radziszewski, P. Skorek, Wykorzystanie destruktu asfaltowego - konieczność i innowacja,
Budownictwo i Architektura 15(1), pp.157-167. (in Polish) (2016).

11. R. Izaksa , V. Haritonovs, I. Klasa , M. Zaumanis, Hot Mix Asphalt With High RAP Content. Procedia Engineering 114 pp. 676 - 684, (2015). doi.org/10.1016/j.proeng.2015.08.009

12. M. Iwański, P. Buczyński, G. Mazurek, The use of gabbro dust in the cold recycling of bitumen paving mixes with foamed bitumen. Bulletin of the Polish Academy of Sciences Technical Sciences 64(4) pp. 763-773, (2016). doi.org/10.1515/bpasts-2016-0085

13. M. Iwański, A. Chomicz-Kowalska, Application of the foamed bitumen and bitumen emulsion to the road base mixes in the deep cold recycling technology. The Baltic Journal of Road and Bridge Engineering 11(4), pp 291-301, (2016). http://dx.doi.org/10.3846/bjrbe.2016.34

14. B. Dołżycki, M. Jaczewski, C. Szydłowski, The long-term properties of mineral-cement-emulsion mixtures, Constr. Build. Mater. 156 pp 799-808, (2017).

doi.org/10.1016/j.conbuildmat.2017.09.032

15. V. Letelier, E. Tarela, P. Muñoz, G. Moriconi, Combined effects of recycled hydrated cement and recycled aggregates on the mechanical properties of concrete. Constr. Build. Mater. 132, pp. 365375

(2017).

doi.org/10.1016/j.conbuildmat.2016.12.010

16. C. Thomas, J. Setién, J.A. Polanco, P. Alaejos, M. Sánchez de Juan, Durability of recycled aggregate concrete. Constr. Build. Mater. 40, pp. 1054-1065, (2013) doi.org/10.1016/j.conbuildmat.2012.11.106

17. L. Evangelista, J. de Brito, Durability performance of concrete made with fine recycled concrete aggregates. Cement and Concrete Composites, 32(1), pp. 9-14, (2010). doi.org/10.1016/j.cemconcomp.2009.09.005

18. M. J. McGinnis, M. D. Andres de la Rosa, B. D. Weldon, Y. C. Kurama, Strength and stiffness of concrete with recycled concrete aggregates. Constr. Build. Mater. 154, pp. 258-269, (2017). doi.org/10.1016/j.conbuildmat.2017.07.015

19. Ahmed Ebrahim Abu El-Maaty Behiry, Utilization of cement treated recycled concrete aggregates as base or subbase layer in Egypt, Ain Shams Engineering Journal 4(4) pp. 661-673, (2013). doi.org/10.1016/j.asej.2013.02.005

20. M. Iwański, A. Chomicz-Kowalska, Application of recycled aggregates to the road base mixtures with foamed bitumen in the cold recycling technology. International Conference on Environmental Engineering (ICEE) 155, pp.1-8, (2014). doi.org/10.3846/enviro.2014.155

21. N.I.Md. Yusoff, G.D. Airey, M.R. Hainin, Predictability of Complex Modulus Using Rheological Models. Asian Journal of Scientific 
Research 3 pp.18-30, (2010). http://dx.doi.org/10.3923/ajsr.2010.18.30

22. C. Godenzoni, A. Graziani, D. Perraton, Complex modulus characterisation of coldrecycled mixtures with foamed bitumen and different contents of reclaimed bitumen. Road Materials and Pavement Design 18(1) pp.130-150, (2017). doi.org/10.1080/14680629.2016.1142467

23. EN 12697-26 Bituminous mixtures. Test methods for hot mix asphalt. Stiffness.

24. Wirtgen Cold Recycling Technology (1rd ed.). Windhagen: Wirtgen GmbH. (2012).

25. OST D-04.10.01a, "The detailed technical specifications: The road base of the mineralcement with foamed bitumen mixture made in cold recycling technology”. Warsaw, GDDKiA. (2013). (in Polish)

26. EN-12697-31 Bituminous mixtures. Test methods for hot mix asphalt. Specimen preparation by gyratory compactom

27. A. Grilli, A. Graziani, M. Bocci, Compactability and thermal sensitivity of cement-Bitumen treated materials. Road Materials and Pavement Design, 13(4) pp. 599-617, (2012). https://doi.org/10.1080/14680629.2012.742624

28. B. Dołżycki, M. Jaczewski, C. Szydłowski, The long-term properties of mineral-cement-emulsion mixtures. Constr. Build. Mater. 156, pp. $799-808$, (2017). doi.org/10.1016/j.conbuildmat.2017.09.032

29. G.M Rowe, M.J. Sharrock, Alternate Shift Factor Relationship for Describing the Temperature
Dependency of the Visco-Elastic Behaviour of Asphalt Materials. Transportation Research Record, 2207, pp 125-135, (2011).

30. M.W. Witczak, R.E. Root, Summary of Complex Modulus Laboratory Test Procedures and Results. STP 561, American Society for Testing and Materials, pp. 67-94, (1976).

31. N.I.Md Yusoff, G.D. Airey M.R. Hainin, Predictability of Complex Modulus Using Rheological Models. Asian Journal of Scientific Research 3, pp 18-30, (2010).

32. G. Mazurek, M. Iwański, Modelling of Asphalt Concrete Stiffness in the Linear Viscoelastic Region. IOP Publishing. IOP Conf. Ser.: Materials Science and Engineering 245:032029, pp. 1-10, (2017). doi:10.1088/1757-899X/245/3/032029.

33. A.C. Pronk, M. Gajewski, W. Bańkowski, Processing of four point bending test results for visco-elasticity and fatigue models. International Journal of Pavement Engineering pp. 1-5, (2017). doi.org/10.1080/10298436.2017.1398549

34. J. Król, K. Kowalski, P. Radziszewski, Rheological behavior of n-alkane modified bitumen in aspect of Warm Mix Asphalt technology, Constr. Build. Mater. 93, pp.703-710, (2015). DOI:10.1016/j.conbuildmat.2015.06.033.

35. G. Mazurek, M. Iwański, Relaxation Modulus of SMA with Polymer Modified and Highly Polymer Modified Bitumen, Procedia Engineering 172, pp. 731-738, (2017). doi.org/10.1016/j.proeng.2017.02.093. 